\title{
Screening of Pigeonpea Genotypes against Tur Pod Fly, Melanagromyza obtusa (Malloch) in Agro-Ecosystem
}

\author{
Maneesh Kumar Singh, Ram Keval, Snehel Chakravarty and Vijay Kumar Mishra* \\ Department of Entomology and Agricultural Zoology, Institute of Agricultural Sciences, \\ Banaras Hindu University, Varanasi-221 005, India \\ *Corresponding author
}

\begin{tabular}{|c|c|}
\hline & A B S T R A C T \\
\hline $\begin{array}{l}\text { K e y w o r d s } \\
\text { Pigeonpea, } \\
\text { Genotypes, } \\
\text { Screening, Pod fly, } \\
\text { Pod and Grain } \\
\text { damage. }\end{array}$ & \multirow{3}{*}{$\begin{array}{l}\text { Twenty nine long duration pigeonpea genotypes were screened for their reaction against } \\
\text { pod fly during Kharif } 2014-15 \text { at the Agricultural Research Farm, Institute of Agricultural } \\
\text { Sciences, Banaras Hindu University, Varanasi. The first incidence of pod fly was observed } \\
\text { in the } 4^{\text {th }} \text { standard week in all genotypes except IVT-509, AVT- } 607 \text { and AVT- } 605 \text { and the } \\
\text { population persisted up to } 12^{\text {th }} \text { standard week in all the genotypes. The peak population of } \\
\text { pod fly irrespective of the genotype/cultivar was recorded in } 11^{\text {th }} \text { standard week. The mean } \\
\text { populations of pod fly on different genotypes ranged from } 0.61 \text { pod fly maggots } 10 \text { pods } \\
\text { in IVT-520 to } 1.57 \text { pod fly maggots/ } 10 \text { pods in IVT-510. The per cent pod damage due to } \\
\text { pod fly significantly varied from } 22.33 \text { per cent in genotype IVT-520 to } 46.67 \text { per cent in } \\
\text { genotype IVT-510. The highest grain damage by pod fly was also seen in IVT-510 } \\
\text { (20.96\%) while the lowest grain damage was observed in IVT-520 (10.67\%). The grain } \\
\text { yield of different genotypes also differed significantly and ranged from } 479 \mathrm{~kg} / \text { ha in the } \\
\text { genotype IVT-510 to } 3314 \mathrm{~kg} / \text { ha in IVT-520. }\end{array}$} \\
\hline Article Info & \\
\hline $\begin{array}{l}\text { Accepted: } \\
\text { 24 February } 2017 \\
\text { Available Online: } \\
\text { 10 March } 2017\end{array}$ & \\
\hline
\end{tabular}

\section{Introduction}

Pigeonpea [Cajanus cajan (L.) Millsp.] is an important legume crop grown in the tropics and subtropics, mostly in Asia, Africa, Latin America and the Caribbean region occupying 6.5 per cent of the world's total pulse area and contributing 5.7 per cent to the total pulse production (ICRISAT, 2012). It is important in semi-arid cropping systems due to its efficient nitrogen-fixing ability, tolerance to drought and contribution to soil organic matter. Pigeonpea also contains high amount of quality dietary protein and thus is an important source of nutrition to vegetarian population. India has virtual monopoly in pigeonpea production accounting to 90 per cent of world's total production. In India, it occupies an area of 3.88 million ha with a production of 3.29 million tonnes (Anonymous, 2014).

Though, India is largest producer of pigeonpea, contributing more than 90 per cent of the world's production, the productivity has always been a cause of concern. The low productivity of pigeonpea in the country may be attributed to many reasons, among which damage by insect pests is of paramount importance (Mishra et al., 2012). Sachan et al., (1994) have reported that pigeonpea is attacked by nearly 250 species of insects' 
worldwide belonging to 8 orders and 61 families though relatively few cause serious yield losses. Amongst many insect pests attacking pigeonpea, pod fly, Melanagromyza obtusa (Malloch) (Diptera: Agromyzidae), is one of the major limiting factors affecting its production.

This insect has a very narrow host range and only feeds on pigeonpea and closely related species. Pod fly infested pods do not show external evidence of damage until the fully grown larvae chew holes in the pod walls. This hole provides an emergence "window" through which the adults exit the pod. The concealed mode of life within the pod makes it difficult to control, with chemical insecticides (Subharani and Singh, 2010). In a survey conducted by ICRISAT, $M$. obtusa is reported to cause 22.5 per cent damage to pigeonpea pods in north India, 21 per cent in central India and 13.2 per cent in south India (Lateef and Reed, 1981). In U.P. the annual loss in pigeonpea production due to pod fly alone has been estimated to the extent of 25 to 30 per cent (Lal and Sachan, 1992).

Host plant resistance plays a very important role in governing the pest infestation level in pigeonpea and screening is an appropriate method to identify resistant genotypes. Identification and cultivation of cultivars which are less preferred by pod fly have number of advantages, particularly for an ecofriendly management of this insect pest on pigeonpea. Since levels of resistance to this pest in the cultivated pigeonpea cultivars are low to moderate, thus it is important to identify pigeonpea cultivars that permit slow growth or lesser population buildup of pod fly. However, Singh and Singh (1990) reported that no definite conclusions could be drawn about the relative susceptibility of pigeonpea genotypes to pod fly damage because of staggered flowering and variation in pod fly abundance over time. Thus, keeping these views in mind, the present study was conducted to identify resistant sources so as to evolve long duration cultivars less susceptible to pod fly in pigeonpea.

\section{Materials and Methods}

The present investigation was carried out at Agricultural Research Farm, Institute of Agricultural Sciences, Banaras Hindu University, Varanasi during Kharif, 2014-15. Twenty nine pigeonpea genotypes/varieties [IVT-501, IVT-502, IVT-503, IVT-504, IVT505, IVT-506, IVT-507, IVT-508, IVT-509, IVT-510, IVT-511, IVT-512, IVT-513, IVT514, IVT-515, IVT-516, IVT-517, IVT-518, IVT-519, IVT-519, IVT-520, IVT-521, AVT601, AVT-602, AVT-603, AVT-604, AVT605, AVT-606, AVT-607, AVT(MAL13*846)] were grown each in plots of 3 rows of $4 \mathrm{~m}$ length following row to row and plant to plant spacing of $75 \mathrm{~cm}$ and $30 \mathrm{~cm}$ respectively. The crop was grown following the normal agronomic practices in "Randomized Block Design (RBD)" with three replications. The crop was sown on $26^{\text {th }}$ July $2014\left(30^{\text {th }}\right.$ standard week) and harvested on $7^{\text {th }}$ April $2015\left(15^{\text {th }}\right.$ standard week) respectively.

The population of pod fly was recorded by observing 10 pods selected randomly out of 100 pods picked up from 5 selected plants in each treatment. The number of insect count recorded from all the three replications and for all the genotypes were averaged separately for each genotype on standard week basis. The sampling for pod and seed damage assessment due to pod fly was done at $80 \%$ maturity stage of the crop. For pod and grain damage assessment, five plants from the three central rows in each plot were selected randomly and all the pods from five plants were pooled together and finally 100 pods were picked up and observations were recorded. Later, the percent pod and grain 
damage was also worked out. The grain yield was also recorded for each plot after excluding the border rows on the two sides of the plot and then extrapolated into $\mathrm{kg} / \mathrm{ha}$.

\section{Statistical analysis}

All the data recorded were subjected to statistical analysis as per the Randomized Block Design procedure. The insect population data were transformed with square root transformation $\sqrt{ } \mathrm{x}+0.5$ method and damage assessment data were transformed by $\operatorname{arc} \sin (\mathrm{q}=\sin -1 \mathrm{x})$ transformation method.

\section{Results and Discussion}

Twenty nine pigeonpea genotypes/varieties were screened under unprotected conditions for studying the damage assessment in relation to per cent pod and grain damage due to pod fly during 2014-15. The results obtained from the investigation as well as relevant discussion have been summarized under the following heads:

Incidence pattern of pod fly, M.obtusa in different pigeonpea genotypes

The first incidence of pod fly was observed in the $4^{\text {th }}$ standard week on $24^{\text {th }}$ January in all genotypes except IVT-509, AVT-607 and AVT-605 (Table 1) and the population persisted up to $12^{\text {th }}$ standard week in all the genotypes. The peak population of pod fly irrespective of the genotype/cultivar was in $11^{\text {th }}$ standard week and thereafter, it declined due to maturity of the grains. The mean populations of pod fly on different genotypes differed significantly and ranged from 0.61 pod fly maggots/ 10 pods in IVT-520 to 1.57 pod fly maggots/ 10 pods in IVT-510 (Figure $1)$. The results are in agreement with Kumar and Nath (2003) who reported that the activity of pod fly (Melanagromyza obtusa) infestation was observed from $23^{\text {rd }}$ January to $8^{\text {th }}$ April. Its peak population was recorded on $22^{\text {nd }}$ February. The present findings are also in agreements to the reports of Jaisal et al., (2010) and Nath et al., (2008). Srujana and Keval (2014) also studied seasonal incidence pattern of tur pod fly on long duration pigeon pea (Bahar). Highest mean population of $M$. obtusa was observed in $9^{\text {th }}$ standard week (7.0 maggots/ 10 pods), followed by $12^{\text {th }}$ standard week (6.8 maggots/ 10 pods) and lowest population (0.8 maggots/ 10 pods) was recorded in the $1^{\text {st }}$ standard week.

Extent of damage caused by pod fly, $M$. obtusa in different pigeonpea genotypes

The data presented in table 2 depicted the per cent pod damage and grain damage by pod fly on different pigeonpea genotypes during 2014-15. The per cent pod damage caused by pod fly on different genotypes varied significantly. It ranged from 22.33 per cent in genotype IVT-520 to 46.67 per cent in genotype IVT- 510. Maximum pod damage due to pod fly were seen in IVT-510 (46.67\%) followed by IVT-502 (45.67\%) and IVT-501 $(45.00 \%)$ and lowest pod damage was observed in IVT-520 (22.33\%) followed by IVT-509 (29.80\%) and AVT-603 (34.33\%). The per cent grain damage due to pod fly also showed differences among the genotypes. It ranged from 10.67 per cent in genotype IVT520 to 20.96 per cent in genotype IVT-510. The highest grain damage by pod fly were seen in IVT-510 (20.96\%) followed by IVT502 (19.67\%), IVT-501 (19.17\%) and lowest grain damage was observed in IVT-520 $(10.67 \%)$ followed by IVT-509 (12.05\%), AVT-603 (13.92\%).

Mishra et al., (2012) reported that among the 50 pigeonpea germplasms, a wide range of variation of pod (18.33 to $47.00 \%)$ and seed (16.43 to $48.44 \%$ ) damage by pod fly were recorded with average mean of 30.68 and $31.69 \%$, respectively. 
Table.1 Population of tur pod fly, M. obtusa on pigeon pea genotypes during Kharif 2014-15

\begin{tabular}{|c|c|c|c|c|c|c|c|c|c|c|}
\hline \multirow[t]{2}{*}{ Genotypes } & \multicolumn{10}{|c|}{ Number of maggots per 10 pods* } \\
\hline & $\begin{array}{l}4^{\text {th }} \text { S.W. } \\
24 \text { Jan. }\end{array}$ & $\begin{array}{l}5^{\text {th }} \text { S.W. } \\
31 \text { Jan. }\end{array}$ & $\begin{array}{c}6^{\text {th }} \text { S.W. } \\
7 \text { Feb. }\end{array}$ & $\begin{array}{l}7^{\text {th }} \text { S.W. } \\
14 \text { Feb. }\end{array}$ & $\begin{array}{l}8^{\text {th }} \text { S.W. } \\
21 \text { Feb. }\end{array}$ & $\begin{array}{l}9^{\text {th }} \text { S.W. } \\
28 \text { Feb. }\end{array}$ & $\begin{array}{c}10^{\text {th }} \text { S.W. } \\
6 \text { Mar. }\end{array}$ & $\begin{array}{l}11^{\text {th }} \text { S.W. } \\
13 \text { Mar. }\end{array}$ & $\begin{array}{c}12^{\text {th }} \text { S.W. } \\
20 \text { Mar. }\end{array}$ & $\begin{array}{c}\text { Overall } \\
\text { mean }\end{array}$ \\
\hline IVT-501 & $0.18(1.082)$ & $0.82(1.100)$ & $0.21(1.127)$ & $0.84(1.349)$ & $0.27(1.600)$ & $0.82(1.833)$ & $1.56(1.947)$ & $2.36(1.718)$ & $1.46(1.568)$ & 1.29 \\
\hline IVT-502 & $0.39(1.179)$ & $0.94(1.224)$ & $0.50(1.300)$ & $1.00(1.382)$ & 0.69 (1.619) & $0.91(1.856)$ & $1.62(1.970)$ & $2.43(1.749)$ & $1.55(1.597)$ & 1.45 \\
\hline IVT-503 & $0.33(1.058)$ & $0.91(1.044)$ & $0.09(1.077)$ & 0.77 (1.237) & $0.16(1.311)$ & $0.53(1.676)$ & $0.72(1.726)$ & $1.81(1.682)$ & $1.38(1.543)$ & 0.98 \\
\hline IVT-504 & $0.15(1.072)$ & $0.81(1.183)$ & $0.40(1.143)$ & 0.95 (1.159) & $0.30(1.292)$ & $0.34(1.500)$ & $0.67(1.565)$ & $1.25(1.490)$ & $0.89(1.375)$ & 0.74 \\
\hline IVT-505 & $0.17(1.081)$ & $0.82(1.049)$ & $0.10(1.167)$ & $0.77(1.200)$ & $0.36(1.326)$ & $0.44(1.536)$ & $0.76(1.622)$ & $1.36(1.562)$ & $0.96(1.400)$ & 0.80 \\
\hline IVT-506 & $0.17(1.166)$ & $0.82(1.118)$ & $0.25(1.269)$ & $0.87(1.311)$ & $0.61(1.356)$ & $0.72(1.703)$ & $0.86(1.775)$ & $1.90(1.700)$ & $1.42(1.556)$ & 1.11 \\
\hline IVT-507 & $0.21(1.072)$ & $0.84(1.086)$ & 0.18 (1.191) & $0.82(1.229)$ & $0.42(1.319)$ & $0.51(1.556)$ & $0.74(1.587)$ & $1.42(1.594)$ & $1.13(1.459)$ & 0.86 \\
\hline IVT-508 & $0.26(1.122)$ & $0.87(1.030)$ & $0.06(1.216)$ & $0.75(1.140)$ & $0.48(1.338)$ & $0.30(1.584)$ & $0.79(1.679)$ & $1.51(1.631)$ & $1.21(1.486)$ & 0.90 \\
\hline IVT-509 & $0.00(1.000)$ & $0.71(1.118)$ & $0.25(1.105)$ & $0.87(1.256)$ & $0.22(1.237)$ & $0.58(1.463)$ & $0.53(1.526)$ & $1.14(1.463)$ & $0.82(1.349)$ & 0.67 \\
\hline IVT-510 & $0.42(1.189)$ & $0.96(1.249)$ & $0.56(1.308)$ & $1.03(1.407)$ & $0.71(1.689)$ & $0.98(1.903)$ & $1.80(2.049)$ & $2.62(1.794)$ & $1.61(1.615)$ & 1.57 \\
\hline IVT-511 & $0.22(1.104)$ & $0.85(1.063)$ & $0.13(1.208)$ & $0.79(1.233)$ & $0.46(1.334)$ & $0.52(1.575)$ & $0.78(1.643)$ & $1.48(1.625)$ & $1.14(1.462)$ & 0.90 \\
\hline IVT-512 & $0.37(1.081)$ & $0.93(1.095)$ & $0.20(1.118)$ & $0.84(1.269)$ & $0.25(1.342)$ & $0.61(1.652)$ & $0.80(1.700)$ & 1.73 (1.627) & $1.29(1.513)$ & 0.98 \\
\hline IVT-513 & $0.29(1.136)$ & $0.89(1.217)$ & $0.48(1.292)$ & $0.99(1.375)$ & $0.67(1.556)$ & 0.89 (1.817) & $1.42(1.889)$ & $2.30(1.726)$ & $1.5(1.581)$ & 1.34 \\
\hline IVT-514 & $0.40(1.183)$ & $0.95(1.162)$ & $0.35(1.221)$ & $0.92(1.265)$ & $0.49(1.341)$ & $0.60(1.612)$ & $0.80(1.673)$ & $1.60(1.631)$ & $1.27(1.507)$ & 1.00 \\
\hline IVT-515 & $0.27(1.000)$ & $0.88(1.175)$ & $0.38(1.216)$ & $0.94(1.149)$ & $0.48(1.254)$ & $0.32(1.497)$ & $0.58(1.530)$ & $1.24(1.476)$ & $0.95(1.396)$ & 0.75 \\
\hline IVT-516 & $0.32(1.149)$ & $0.91(1.179)$ & 0.39 (1.257) & $0.94(1.308)$ & $0.58(1.364)$ & $0.71(1.70)$ & $0.86(1.755)$ & 1.89 (1.677) & $1.39(1.546)$ & 1.11 \\
\hline IVT-517 & $0.40(1.183)$ & $0.95(1.212)$ & $0.47(1.269)$ & $0.98(1.327)$ & $0.61(1.456)$ & $0.76(1.794)$ & $1.12(1.857)$ & $2.22(1.715)$ & $1.45(1.565)$ & 1.27 \\
\hline IVT-518 & $0.20(1.095)$ & $0.84(1.122)$ & $0.26(1.191)$ & $0.87(1.237)$ & $0.42(1.337)$ & $0.53(1.572)$ & $0.79(1.615)$ & $1.47(1.622)$ & $1.09(1.446)$ & 0.89 \\
\hline IVT-519 & $0.11(1.054)$ & $0.78(1.113)$ & $0.24(1.140)$ & $0.86(1.170)$ & $0.30(1.296)$ & $0.37(1.500)$ & $0.68(1.549)$ & $1.25(1.503)$ & $0.91(1.382)$ & 0.72 \\
\hline IVT-520 & $0.12(1.127)$ & $0.79(1.025)$ & 0.05 (1.179) & $0.74(1.131)$ & $0.39(1.212)$ & $0.28(1.425)$ & $0.47(1.496)$ & $1.03(1.432)$ & $0.89(1.375)$ & 0.61 \\
\hline IVT-521 & $0.31(1.145)$ & $0.90(1.183)$ & $0.40(1.233)$ & $0.95(1.288)$ & $0.52(1.353)$ & $0.66(1.674)$ & $0.83(1.703)$ & $1.80(1.652)$ & $1.29(1.513)$ & 1.05 \\
\hline AVT-601 & $0.41(1.149)$ & $0.95(1.114)$ & $0.24(1.136)$ & $0.86(1.268)$ & $0.29(1.347)$ & $0.61(1.676)$ & $0.81(1.743)$ & $1.81(1.708)$ & $1.42(1.556)$ & 1.05 \\
\hline AVT-602 & $0.36(1.166)$ & $0.93(1.075)$ & $0.16(1.153)$ & $0.81(1.233)$ & $0.33(1.307)$ & $0.52(1.562)$ & $0.71(1.625)$ & $1.44(1.600)$ & $1.03(1.424)$ & 0.86 \\
\hline AVT-603 & $0.31(1.140)$ & $0.90(1.083)$ & $0.17(1.199)$ & $0.82(1.165)$ & $0.43(1.222)$ & $0.36(1.456)$ & $0.56(1.500)$ & $1.12(1.453)$ & $0.91(1.382)$ & 0.69 \\
\hline AVT-604 & $0.30(1.100)$ & $0.89(1.058)$ & $0.12(1.235)$ & $0.79(1.169)$ & $0.56(1.536)$ & $0.37(1.778)$ & $1.36(1.868)$ & $2.16(1.701)$ & $1.00(1.414)$ & 1.14 \\
\hline AVT-605 & $0.00(1.000)$ & $0.71(1.14)$ & $0.30(1.167)$ & $0.89(1.216)$ & $0.37(1.317)$ & $0.48(1.543)$ & $0.73(1.619)$ & $1.38(1.587)$ & $0.99(1.412)$ & 0.82 \\
\hline AVT-606 & $0.02(1.086)$ & $0.72(1.249)$ & $0.56(1.086)$ & $1.03(1.247)$ & $0.18(1.329)$ & $0.39(1.568)$ & $0.76(1.613)$ & $1.46(1.606)$ & $1.18(1.476)$ & 0.86 \\
\hline AVT-607 & $0.00(1.000)$ & $0.71(1.104)$ & $0.22(1.183)$ & $0.85(1.187)$ & $0.40(1.304)$ & $0.41(1.517)$ & $0.70(1.578)$ & $1.30(1.549)$ & $0.92(1.385)$ & 0.76 \\
\hline MAL13*846 (Check) & $0.32(1.170)$ & $0.90(1.158)$ & $0.34(1.204)$ & $0.92(1.118)$ & $0.45(1.337)$ & $0.25(1.581)$ & $0.78(1.646)$ & $1.50(1.612)$ & $1.21(1.486)$ & 0.91 \\
\hline $\mathrm{SE}(\mathbf{m}) \pm$ & 0.008 & 0.008 & 0.012 & 0.015 & 0.019 & 0.010 & 0.012 & 0.012 & 0.013 & - \\
\hline CD at $5 \%$ & 0.022 & 0.023 & 0.034 & 0.042 & 0.055 & 0.030 & 0.035 & 0.035 & 0.038 & - \\
\hline
\end{tabular}

*Figures in parentheses are $\sqrt{x}+0.5$ transformed value; $S W=$ Standard Week 
Table.2 Extent of damage caused by pod fly and yield of different long duration pigeonpea genotypes during 2014-15

\begin{tabular}{|c|c|c|c|}
\hline Genotypes & \% Pod Damage* & $\%$ Grain Damage* & Yield (kg/ha) \\
\hline IVT-501 & $45.00(43.45)$ & $19.17(25.90)$ & 1300 \\
\hline IVT-502 & $45.67(42.40)$ & $19.67(26.29)$ & 1244 \\
\hline IVT-503 & $43.00(40.95)$ & $18.41(25.29)$ & 2775 \\
\hline IVT-504 & $32.45(34.55)$ & $15.98(23.50)$ & 2801 \\
\hline IVT-505 & $34.67(35.76)$ & $14.00(21.91)$ & 1698 \\
\hline IVT-506 & $42.00(40.36)$ & $17.63(24.76)$ & 2836 \\
\hline IVT-507 & $35.00(36.48)$ & $14.67(22.50)$ & 1725 \\
\hline IVT-508 & $35.67(36.35)$ & $12.99(20.99)$ & 2166 \\
\hline IVT-509 & $29.80(28.60)$ & $12.05(20.27)$ & 3199 \\
\hline IVT-510 & $46.67(43.07)$ & $20.96(27.23)$ & 479 \\
\hline IVT-511 & $36.67(36.43)$ & $15.86(23.44)$ & 1992 \\
\hline IVT-512 & $42.45(40.61)$ & $17.72(24.68)$ & 1304 \\
\hline IVT-513 & $40.33(39.18)$ & $16.13(23.63)$ & 2295 \\
\hline IVT-514 & $39.00(38.62)$ & $17.89(24.76)$ & 2592 \\
\hline IVT-515 & $39.00(38.72)$ & $16.13(23.64)$ & 2268 \\
\hline IVT-516 & 33.67 ( 35.19$)$ & $13.67(21.49)$ & 2083 \\
\hline IVT-517 & $40.33(39.28)$ & $18.06(25.03)$ & 2381 \\
\hline IVT-518 & $39.67(38.77)$ & $16.67(24.19)$ & 2652 \\
\hline IVT-519 & $34.33(35.80)$ & $16.55(23.95)$ & 2504 \\
\hline IVT-520 & $22.33(27.96)$ & $10.67(18.95)$ & 3314 \\
\hline IVT-521 & $38.33(28.17)$ & $14.33(22.09)$ & 2674 \\
\hline AVT-601 & $39.00(38.62)$ & $16.93(24.26)$ & 2393 \\
\hline AVT-602 & 40.33 ( 39.39) & $17.63(24.78)$ & 2164 \\
\hline AVT-603 & 34.33 ( 35.69$)$ & $13.92(21.04)$ & 3196 \\
\hline AVT-604 & $36.00(36.81)$ & $16.06(23.60)$ & 2752 \\
\hline AVT-605 & $37.00(37.50)$ & $15.57(23.17)$ & 2395 \\
\hline AVT-606 & 41.67 ( 40.17) & $17.89(24.97)$ & 2025 \\
\hline AVT-607 & $38.00(38.00)$ & $15.43(23.11)$ & 2994 \\
\hline AVT-MAL13*846 (Check) & $39.33(38.67)$ & $15.42(23.05)$ & 2293 \\
\hline $\mathrm{SE}(\mathbf{m}) \pm$ & 1.687 & 1.627 & - \\
\hline CD at $5 \%$ & 4.791 & N/A & - \\
\hline
\end{tabular}

*Figures in parentheses are arc sin transformed values 
Figure.1 Population fluctuation of tur pod fly on different pigeonpea genotypes during Kharif 2014-15

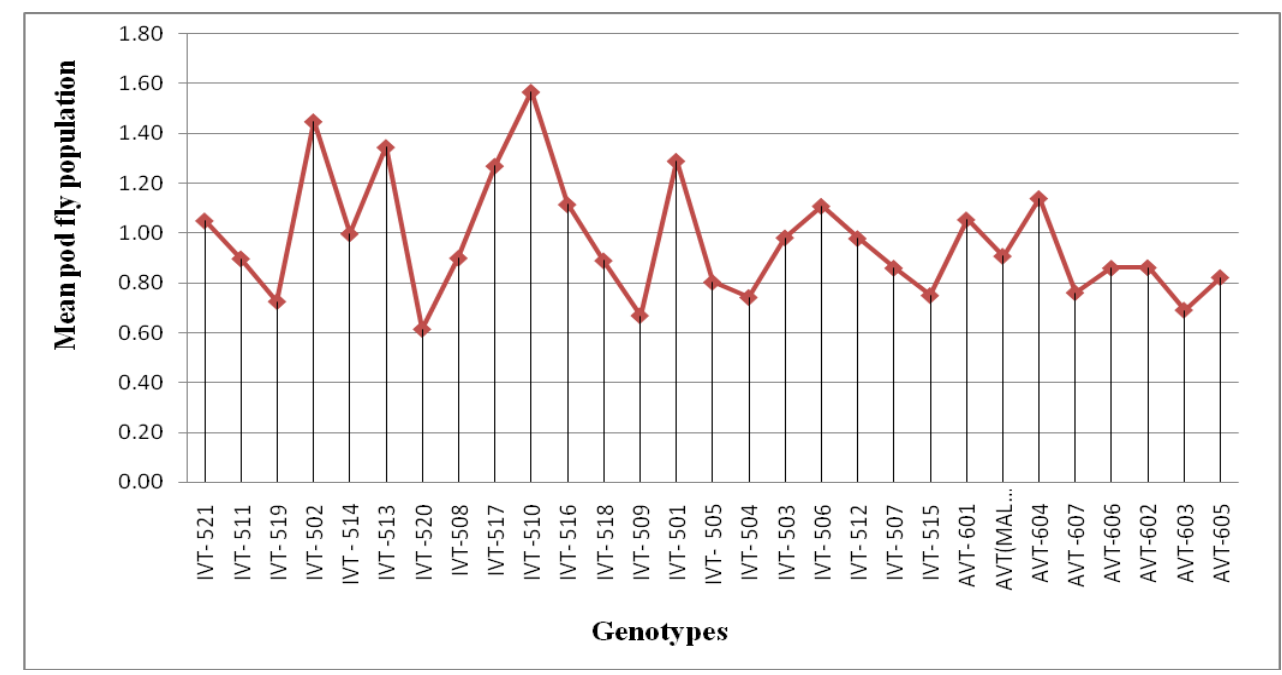

On the basis of pooled mean, two lines viz., ICP 2514 (18.33\%) and ICP $2454(19.33 \%)$ revealed resistance against the pod damage caused by pod fly, respectively whereas, based on seed damage ICP 2459 (16.43\%) and ICP $2155(18.62 \%)$ were categorized as resistant. This may be due to difference in susceptibility of genotypes to pod fly. Srivastava and Mohapatra (2002) also reported that the extent of pod damage inflicted by lepidopteran pod borers and pod fly on fifteen pigeonpea genotypes varied from 1.0 to 6.3 per cent and 15.1 to 33.1 per cent, respectively. Various authors all over the country have rated the pod fly as the serious pest in northern part of India (Kumar et al., 1998; Reddy et al., 1998; Minja et al., 2000).The present finding corroborates with the findings of these authors.

\section{Grain yield}

The data on grain yield per hectare of different genotypes are given in Table 3. There was significant difference in grain yield among the genotypes. The highest grain yield was recorded from IVT $520(3314 \mathrm{~kg} / \mathrm{ha})$ which was significantly different from other genotypes where as the lowest grain yield was recorded from IVT-510 (479 kg/ha). These findings are in conformity with Banu et al., (2007) and Borad et al., (1991) who also reported higher yield potential in those pigeonpea genotypes which showed lesser incidence of pod borers.

On the basis of the above investigation it may be concluded that host plant resistance plays a very important part in governing the pest infestation level in pigeonpea. The pod fly, Melanagromyza obtusa (Malloch) is a cardinal insect pest on pigeonpea in this zone and its incidence increases with the advancement of crop age. Actual damage to the economic produce also takes place after flowering in case of pulses. Among the twenty nine genotypes screened, IVT-520, IVT-509 and AVT-603 were found to be most tolerant against pod fly damage and hence should be promoted.

\section{References}

Anonymous. 2014. Agricultural statistics at a glance, Department of Agriculture and Cooperation, Ministry of Agriculture, Government of India, p. 97.

Banu, M.R., Muthiah, A.R., Ashok, S. 2007. 
Field screening and evaluation of pigeonpea genotypes against pod borer (Helicoverpa armigera). Pak. J. Biol. Sci., 10(7): 1149-1150.

Borad, P.K., Patel, J.R., Patel, M.G. 1991. Evaluation of vegetable pigeonpea genotypes resistance to gram pod borer, plume moth and pod fly. Indian $J$. Agric. Sci., 61: 682-684.

ICRISAT. 2012. http://www.icrisat.org (Accessed 26 May, 2014)

Jaisal, J.K., Srivastava, C.P. and Sharma, R.P. 2010. Resistance in long duration pigeonpea against major insect pests. Ann. Pl. Protec. Sci., 18(2): 501-502.

Kumar, R., Ali, S., Singh, B.B., Singh, R.K. and Kumar R. 1998. Screening of pigeonpea germplasm against tur podfly. Indian J. Pulses Res., 11(1): 118-119.

Kumar A. and Nath P. 2003. Pest complex and their population dynamics on medium-late variety of, Bahar. Indian J. Pulses Res., 16(2): 150-154.

Lal, S.S. and Sachan, J.N. 1991. Controlling pod fly, Melanagromyza obtusa in late pigeonpea through host-plant resistance. Int. Pigeonpea Newsl., 15: 28-30.

Lateef, S.S. and Reed, W. 1981. Survey of insect pest damage in farmer's field in India. Int. Pigeonpea Newsl., 1: 29-30.

Minja, E.M., Silim, S.N. and Karuru, O. 2000. Insect pest incidence on long-duration Uganda lines at Kabete in Kenya. Int. Chickpea Pigeonpea Newsl., 7: 56-57.

Mishra, M.K., Singh, R.P. and Ali, S. 2012. Chemical control and avoidable yield losses of pigeonpea due to insect pests. Ann. Pl. Protec. Sci., 20: 306-309.

Nath, P., Singh, R.S., Singh, P.S. and Keval, R. 2008. Study of the succession of insect pest associated with pods of pigeonpea under sole and intercropping system. Indian J. Environ. Ecoplan. 15: 455-461.

Reddy, C.N., Singh, Y. and Singh, V.S. 1998. Pest complex and their succession on variety P-33. Indian J. Entomol., 60(4): 334-338.

Sachan, J.N., Yadava, C.P., Ahmad, R. and Katti, G. 1994. Insect pest management in pulse crops. In: Trends in Agricultural insect pest management, 308-344, New Delhi (Commonwealth Publishers).

Singh, H.K. and Singh, H.N. 1990. Screening of certain pigeonpea cultivars sown at kharif and rabi crops against tur pod bug, Clavigralla gibbosa and pod fly, Melanagromyza obtusa. Indian J. Entomol., 52: 320-327.

Srivastava, C.P. and Mohapatra, S.D. 2002. Field screening of genotypes for resistance to major insect pests. J. App. Zool. Res., 13(2/3): 202-203.

Srujana, Y. and Kewal, R. 2014. Periodic occurrence and association of pod fly and pod bug on long duration pigeonpea (Bahar) with weather parameters. $J$. Exp. Zool., India, 17(2): 595-597.

Subharani, S. and Singh, T.K. 2010. Biology of pod fly, Melanagromyza obtusa on Cajanus cajan in Manipur. Ann. Pl. Protec. Sci., 18: 67-69

\section{How to cite this article:}

Maneesh Kumar Singh, Ram Keval, Snehel Chakravarty and Vijay Kumar Mishra. 2017. Screening of Pigeonpea Genotypes against Tur Pod Fly, Melanagromyza obtusa (Malloch) in Agro-Ecosystem. Int.J.Curr.Microbiol.App.Sci. 6(3): 1911-1917. doi: https://doi.org/10.20546/ijcmas.2017.603.217 